Jurnal Ilmiah Bahasa dan Sastra

Mabasan

Masyarakat Bahasa dan Sastra Nusantara

Vol. 5, No. 2, Juli-Desember 2011

Penanggung Jawab:

Nining Nur Alaini, M. Hum.

Pemimpin Redaksi

Balok Safarudin, S.S.

Dewan Redaksi:

Prof. Dr. Mahsun, M.S. (Universitas Mataram)

Prof. Nurrahman Hanafi (Universitas Mataram)

Dr. Inyo Yos Fernandez (Universitas Gajah Mada)

Prof. Dr. Kisyani Laksono (Universitas Negeri Surabaya)

Prof. Dr. Nadra (Universitas Andalas, Padang)

Redaktur:

Balok Safaruddin, S. S.

Editor:

Hartini, S. Pd.

Redaktur Pelaksana:

Desi Rachmawati, S.Pd.

Syaiful Bahri, S. Pd.

Tata Letak:

Ni Wayan Widiartini, A.Md.

Alamat Redaksi:

Jalan dr. Sujono, Kelurahan Jempong Baru, Kecamatan Sekarbela Mataram 


\section{Pengantar Redaksi}

Tidak ada sesuatu yang terjadi kecuali atas kehendak dan rahmatNya. Oleh karena itu, sudah sepantasnya kami memanjatkan puji syukur ke hadirat Allah SWT karena atas rahmat-Nya Jurnal Ilmiah Mabasan (Masyarakat Bahasa dan Sastra Nusantara) edisi ini dapat hadir di hadapan pembaca sekalian.

Mabasan merupakan jurnal terbitan Kantor Bahasa Provinsi NTB yang memuat tulisan-tulisan ilmiah dan hasil-hasil penelitian yang berkaitan dengan kebahasaan dan kesastraan. Keberadaannya, secara tidak langsung, menjadi salah satu media diskusi maupun penyampaian ide dalam bentuk tulisan. Kami berharap, keberadaannya memberikan sumbangan bagi perkembangan wacana kebahasaan dan kesusatraan di tanah air pada umumnya dan di Provinsi NTB pada khususnya.

Jurnal ini berisi delapan artikel yang ditulis oleh orang dalam maupun luar Kantor Bahasa Provinsi NTB. Semuanya telah melalui proses seleksi dan edit sebelum ditampilkan secara utuh menjadi sebuah jurnal seperti yang Anda pegang.

Terselesaikannya Mabasan ini tentunya tidak terlepas dari bantuan berbagai pihak. Oleh karena itu, kami mengucapkan terima kasih kepada semua pihak yang turut berpartisipasi dalam jurnal ini.

Kami menyadari bahwa jurnal Mabasan ini banyak memiliki kelemahan dan kekurangan. Oleh karena itu, kami sangat mengharapkan kritik, masukan, dan tanggapan dari pembaca demi perbaikan Mabasan edisi mendatang.

\section{Pimpinan Redaksi}




\section{Daftar Isi}

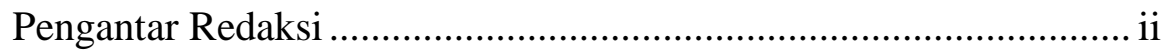

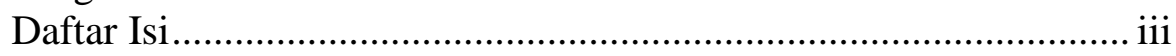

Bahasa Nasional dan Bahasa Lokal di Televisi

Bagi Pembangunan Bangsa

Endang K. Trijanto

Kearifan Lokal dalam Cerita Rakyat Nusantara:

Upaya Melestarikan Budaya Bangsa

Erli Yetti.

Alus Enduk dalam Sistem Tutur Masyarakat Sasak

Lalu Erwan Husnan. 25

Strategi dan Fungsi Linguistik Kekuasaan

dalam Naskah Babad Lombok

Lalu Habiburrahman.

Hakikat Karya Masyarakat Sasak yang Tercermin dalam Sesenggak

Muhammad Shubhi 48

Nilai-Nilai Budaya Sasak Kemidi Rudat Lombok:

Perspektif Hermeneutika

Murahim

Identitas Perempuan yang Terbelenggu dalam Gadis Pantai

Karya Pramoedya Ananta Toer: Subaltern

dalam Konstruksi Sosial Masyarakat Tradisi

Syukrina Rahmawati

Teks Sastra sebagai Media Komunikasi Antarbangsa

(Kajian atas Novel dari Fontenay ke Magallianes Karya NH. Dini)

Tuti Kusniarti 94 